\title{
Mass Appraisal of Land Value by Regression Model
}

\author{
NGUYẼ̃N QUỲNH HOA \\ Doctor of Philosophy, University of Economics HCMC \\ Email:nqhoa@ueh.edu.vn \\ NGUYẼ̃N THẠCH \\ MTV Standard Chartered Bank \\ Email: thachnguyen010190@gmail.com
}

\begin{abstract}
Land is always an extremely important resource to all countries. In managing this limited natural resource, land valuation for the purpose of determining financial obligation for users of land is a crucial issue for governments. This paper presents a method of land valuation based on a regression model that allows approaching market prices of land in a region or district. The research uses data of a survey of 600 samples in HCMC, comprising 318 street-fronting real properties and 282 ones in alleys. Two regression models are developed to conduct valuation of those two kinds of land (street fronting and alley fronting pieces of land). The research results can be used for managing stocks of land and determining financial obligations of land users in HCMC.
\end{abstract}

Keywords: land price, mass appraisal, land valuation, governmental control, regression model 


\section{PROBLEM STATEMENT}

Theories of land valuation recognize six methods of land valuation: (1) comparison, (2) abstraction, (3) allocation, (4) income capitalization, (5) capitalization of ground rent, and (6) land residual. Besides traditional methods of land valuation, mass appraisal of land value by regression model is widely applied using data on land prices with support from statistical softwares.

In Vietnam, land valuation and publicized list of land prices are required tasks set by 2003 Land Law. Legal normative documents providing guidelines on land valuation are Decree 188/2004/NĐ-CP dated Nov. 16, 2004 and Circular 114/2004/TT-BTC dated Nov. 26, 2004; and Decree 123/2007/NĐ-CP dated July 27, 2007 and Circular 145/2007/TT-BTC dated Dec. 6, 2007. These documents introduce four land valuation

methods: (1) comparison, (2) income, (3) abstraction, and (4) land residual. These methods are basically similar to traditional and internationally applied ones, and useful for valuation of separate sites. However, in valuation of land for taxation purpose, appraising land site by site is a time-consuming task that may lead to difficulties and obstacles. In this case, mass appraisal seems to be an effective solution.

\section{LOGICAL GROUNDS}

According to International Association of Assessing Officers (IAAO, 2012), mass appraisal is "the systematic appraisal of groups of properties as of a given date using standardized procedures and statistical testing."

Mass appraisal includes the application of single-property appraisals, as well as the development of appraisal formulas and statistical models, that can be applied uniformly to a number of properties at a time. This method is carried out with support from systems of land information in form of database, by quantifying relations between land values and property attributes using regression analysis techniques.

Mass appraisal through regression analysis helps assessors evaluate an entire city or a surveyed area objectively and scientifically based on data from samples collected from the site. Examining and analyzing natural factors that affect prices of land in a district and applying regression analysis techniques allow establishing relationships between land prices and relevant independent variables.

When conducting mass appraisal, analysts should collect two groups of data: of geographical features and of property attributes (real properties in general and land in 
particular). The data will be used for classification and valuation, as well as other purposes. Collection of data should be based on factors that affect market prices and requirements posed by valuation methods. Benefits and marginal costs of data collection and storage should be also taken into consideration.

Computer-assisted mass appraisal was developed and applied by John Q. Ebert in Lansing, Michigan in 1965, and further implemented in Spartanburg County, South Carolina in 1970. Research on mass appraisal by John Q. Ebert \& Robert J. Anderson was presented at 1973 IAAO Conference in Florida, and from that point on the term Computer-Assisted Mass Appraisal (CAMA) has become ubiquitous and universal to the many versions of computer-processed mass appraisal systems for property tax administration. Mr. Ebert and Dr. Anderson continued to promote the concept of mass appraisal for property tax administration which soon spread throughout the world.

Afterwards Smith, Root, \& Belloit (1995), Downing \& Clark (1997), Allison (1998), Baldwin (1999), Betts \& Ely (2001), Ratterman (2001), and many other authors conducted series of empirical researches employing regression analyses to evaluate real properties.

P. G. Grabovy (Грабовый П. Г.) et al. (1999) discriminate three mass appraisal models:

(1) Additive model:

$\mathrm{S}=\mathrm{b}_{0}+\mathrm{b}_{1} \mathrm{X}_{1}+\mathrm{b}_{2} \mathrm{X}_{2}+\ldots+\mathrm{b}_{\mathrm{n}} \mathrm{X}_{\mathrm{n}}+$, where

$S$ : dependent variable for value of the site (or piece of land),

$\mathrm{X}_{1}, \mathrm{X}_{2}, \ldots, \mathrm{X}_{\mathrm{n}}$ : independent variables for factors affecting value of the site;

$b_{1}, b_{2}, \ldots, b_{n}$ : regression coefficients; and

$\mathrm{b}_{0}:$ intercept term.

(2) Multiplicative model:

$\mathrm{S}=\mathrm{b}_{0} \cdot \mathrm{X}_{1}{ }^{\mathrm{b} 1} \ldots \cdot \mathrm{X}_{\mathrm{n}}^{\mathrm{bn}}$

In this model, unlike the additive one, independent variables are not multiplied by regression coefficients but turned into power indexes. This model is considered to be able to reflect more exactly simultaneous effects of factors affecting the value of real property.

(3) Mixed model: this is a combination of the two above models. 
P.G. Grabovy also emphasizes that model specification is necessary for identification of regression coefficients, or direct effects of independent variables on market prices of real properties.

A.V. Xevaxtianov (А. В. Севостьянов, 2007) points out factors affecting prices of residential land, including residents' access to city center, public services, technical infrastructure, landscape, development level of public services, environment, and microclimate. Turner (2005) proves that quality of living environment, landscape, local safety, and friendliness of neighbors affect the land price.

At present, mass appraisal method is applied in many countries, such as the US, Sweden, Russia and other European nations. In Russia, mass appraisal for taxation purpose was first introduced in 1998-99 for valuation of agricultural land. Afterwards, it was applied to residential and industrial estate, forests, and reserves. In 2006, the first time after seven years of application of mass appraisal in Russian federation, land tax was determined according to results of mass appraisal of land value.

\section{RESEARCH MODEL}

The paper presents the research on mass appraisal model for urban residential land in HCMC. The research is carried out in the following steps.

Step 1: Studying theory of econometrics by Ramanathan (2002). Theories of realty market, valuation of real properties, mass appraisal and mathematic statistics and previously-developed models are reviewed.

Step 2: Developing theoretical framework.

Step 3: Gathering data appropriate to the model. The data are supplied by professional valuation firms. Prices of land in various districts are reliable because they are assessed by experienced and qualified experts through field investigation.

Step 4: Identifying variables of the model.

Step 5: Establishing the model based on theoretical framework and variables selected from collected data.

Step 6: Estimating the model.

Step 7: Testing for violations of hypotheses. If violations are detected, Step 5 is taken again to make the model more precise, appropriate to hypotheses, and explicable. When models meet statistical standards and hypotheses, Step 8 is taken. 
Step 8: Interpreting research results based on the model, and comparing them to real facts.

Step 9: Predicting trends of land prices based on the acquired regression model.

Step 10: Summarizing interpretive results, and offering recommendations and practical solutions.

Based on the theory of mass appraisal and specific conditions of the realty market in Vietnam, the paper suggests the following model for mass appraisal of land value in HCMC:

$\mathrm{Y}=\beta_{0}+\beta_{\mathrm{i}} \mathrm{X}_{\mathrm{i}}$

where $\mathrm{Y}$ is dependent variable (price of a square meter of land), $\mathrm{X}_{\mathrm{i}}$ is independent variable, $\beta_{\mathrm{i}}$ is regression coefficient, and $\beta_{0}$ is intercept term.

Independent variables, or factors affecting the land value presented in the model, are based on author's observations when studying HCMC market for land use rights.

\section{DESCRIPTION OF VARIABLES AND SAMPLES}

\section{a. Variables:}

* Dependent variables:

DON_GIA (Unit land price): This is a quantitative variable expressed in VND1,000 per square meter. Land price is calculated by deducting remaining value of building on the site from accepted selling price of the real property. The unit land price is calculated by dividing the land price by the recognized area. This research is limited to prices of urban sites.

\section{* Independent variables:}

By studying existing conditions, the authors found that certain variables, such as CAP_HEM (alley grade) might greatly affect the land price of alley-fronting sites but produce no influence on price of street-fronting sites, and vice versa, such as variable LO_GIOI (street size). To obtain more precise estimates, therefore, the authors develop two models, one for street-fronting real properties and one for alley-fronting ones in the hope that independent variables can explain the dependent one better.

AN_NINH: This variable represents safety of the neighborhood and could take values from 1 to 5 (very good, good, acceptable, bad, and very bad). Its expected sign is negative (-). 
CAP_HEM (Grade of alley where real property is located): This qualitative variable is used only for alley-fronting real properties. Inter-department guideline 7575/2008/HDLS and Decision 89/2010/QĐ by HCMC People's Committee set the following grades for alleys.

Alley of grade 1: Alleys directly connected with the street

Alley of grade 2: Alleys connected with the alleys of grade 1 .

Other grades: Alleys connected with alleys of grade 2 .

Field observations show that real properties in alleys of grade 1 are usually dearer than ones in alleys of lower grades. Expected sign of this variable, therefore, is directly proportional to the signs of DON_GIA. This variable is codified by nominal scale into three values: 3 for grade- 1 alley; 2 for grade- 2 alley, and 1 for alleys of other grades.

CR_LD (Front meter): This quantitative variable expresses the dimension of a lot of land measured in meter along the street/alley on which it is situated. Its expected sign is $(+)$.

HD_LD (Shape of the lot): This qualitative variable is codified by nominal scale into the following values: 1 when the lot is L-shaped or has a narrower rear part, 2 if the lot has right angles, and 3 if the lot has a wider rear part. Expected sign is $(+)$.

KC_TP (Distance from the site to city center): This quantitative variable is expressed in minute. This distance from the real property to Bến Thành Market is measured in kilometer pretty exactly by Vietbando software; and this distance is turned into minutes by dividing by average speed of a motorbike ( $30 \mathrm{~km}$ per hour). In fact, the greater the distance, the lower the price of property. It is expected that this variable is inversely proportional to DON_GIA and bears the (-) sign.

KET_CAU (Street/alley quality): Most streets in HCMC are surfaced with blacktop, and therefore this variable is not present in the model for street-fronting properties. In the model for alley-fronting lots, this variable takes value 3 if the alley is blacktopped; value 2 if it is covered with cement or concrete; and value 1 otherwise. Its expected sign is $(+)$.

KET_XE: This variable reflects frequency of traffic jam on the main street leading to the site and takes value 1 if traffic jam is rare, 2 if it is occasional and 3 if it is often. Its expected sign is undecided.

LOAI_DGT (Type of roads on which the property is situated): This is a qualitative variable applied only to street-fronting real properties. Roads in HCMC can be divided 
into three groups: one-way streets, two-way streets, and streets with median strips or barriers.

Field investigation shows that there is almost no difference in prices of real properties on two-way streets and streets with median, and therefore the nominal scale gives this variable a value of 2 if the property is on a two-way street or a street with median and a value of 1 if the property is on a one-way street.

LOAI_HEM: This qualitative variable indicates the type of alley on which the property is situated and only exists in the model for alley-fronting properties. It takes the value 1 if the alley has a dead end and 2 otherwise. Its expected sign is $(+)$.

LOAI_SD (Prevailing type of land usage on the street where the property is located): This qualitative variable may take four values: 4 if it is a hotel, office building, and trade center; 3 if it is a busy and large shop; 2 if it is a small retailing shop; and 1 if it is a residential house. Its expected sign is (+).

LO_GIOI: This quantitative variable represents the size of the street measured in meter and only applies to street-fronting properties. Data about street size are publicized by district authorities in HCMC and by diaoconline.vn. Concerning the streets that the authors could not find information about their sizes, the street size will be equal to distance between two opposite rows of houses on the street. Its expected sign is $(+)$.

MT_ST: This qualitative variable stands for ecological environment in the neighborhood and may be measured by a five-point scale: very good, good, acceptable, slight polluted, and seriously polluted, and their values varies from 1 to 5 in that order. Its expected sign is (-).

VT_HEM: This qualitative variable represents size of alley where the property is located and only applies to such properties. Inter-departmental Guideline7575/2008/HD-LS and Decision 89/2010/QĐ by HCMC People's Committee divide alleys into the following groups:

- Size 1: alleys of five meters wide or broader covered with macadam, blacktop, cement or concrete.

- Size 2: alleys of three to five meters wide covered with macadam, blacktop, cement or concrete. 
- Size 3: alleys of two to three meters wide covered with macadam, blacktop, cement or concrete.

- Size 4: alleys of two meters wide or narrower covered with macadam, blacktop, cement or concrete.

This variable is also codified and takes four values: 4 for size- 1 alleys; 3 for size- 2 alleys; 2 for size-3 alleys and 1 for size-4 alleys. Expected sign is (-).

Variables and their expected signs are summarized in Table 1.

Table 1: Variables for Two Models

\begin{tabular}{ccc}
\hline No. & Model for Alley-Fronting & Model for Street-fronting \\
\hline 1 & DON_GIA & DON_GIA \\
2 & AN_NINH (-) & AN_NINH (-) \\
3 & CAP_HEM (+) & CR_LD (+) \\
4 & CR_LD (+) & HD_LD (+) \\
5 & HD_LD (+) & KC_TP (-) \\
6 & KC_TP (-) & KET_XE (+) (-) \\
7 & KET_CAU (+) & LAI_DGT (+) \\
8 & KET_XE $(+)(-)$ & LOAI_SD (+) \\
9 & LOAI_HEM (+) & LO_GIOI $(+)$ \\
10 & LOAI_SD (+) & \\
11 & MT_ST (-) & \\
12 & VT_HEM (+) & \\
\hline
\end{tabular}

Source: Authors' survey

To ensure an objective estimate, variables AN_NINH, KET_XE, MT_ST are assessed through questionnaires and direct interviews with residents in surveyed neighborhood.

\section{b. Samples:}

To perform regression analysis, the authors gather data about 600 real properties on over 250 streets in 19 urban districts and five rural ones of HCMC; 318 of which are street-fronting properties and 282 are alley-fronting ones. The data are from assessment documents supplied by Exim Valuation JSC and Đại Việt Auction and Valuation Ltd. These properties were traded successfully in the period from October 
2011 to April 2012. These properties may have or not have buildings on them. Values of buildings are estimated and deducted from the selling prices of properties because the research only focuses on land price. Results of such estimates and calculations are reliable because they are conducted by professional assessors.

Of 318 street-fronting samples, the ones on Lê Lợi street (District 1) are the most expensive (VND729,207,000 per square meter) and the cheapest ones are found on Hiệp Thành 18 Street of District 12 (VND11,483,000).

Regarding prices of alley-fronting properties, the highest are on Lê Lai Street (District 1) (VND191,791,000 per $\mathrm{m}^{2}$ ) and the lowest are on Đồng Tâm Street of Hóc Môn District (VND3,550,000). All property samples are traded legally; therefore, no variable about legal issue is included in the research.

\section{RESULTS FROM REGRESSION MODELS}

\section{a. Model for Alley-Fronting Properties:}

After conducting the first regression (Model 1), variables with no statistical significance (Sig. $>0.05$ ) are removed. In Model 2, there are six variables left. Results of regression models for alley-fronting properties are presented in Table 2.

Table 2: Results of Regression Models for Alley-fronting Properties

\begin{tabular}{|c|c|c|c|c|}
\hline \multirow{2}{*}{ Variable } & \multicolumn{2}{|c|}{ Model 1} & \multicolumn{2}{|c|}{ Model 2} \\
\hline & B & Sig. & B & Sig. \\
\hline Constant & $29,653.9$ & 0.103 & 16,535 & 0.093 \\
\hline AN_NINH & $-6,263.3$ & 0.072 & $-6,572.1$ & 0.022 \\
\hline CAP_HEM & $3,671.9$ & 0.007 & $3,297.9$ & 0.014 \\
\hline $\mathrm{KC} \_\mathrm{TP}$ & $-2,136.1$ & 0.000 & $-2,077.7$ & 0.000 \\
\hline KET_CAU & $5,108.7$ & 0.010 & $5,071.2$ & 0.010 \\
\hline LOAI_SD & $28,766.5$ & 0.000 & $29,206.7$ & 0.000 \\
\hline VT_HEM & $4,585.4$ & 0.007 & $3,643.7$ & 0.026 \\
\hline HD_LD & $-1,688.7$ & 0.442 & & \\
\hline KET_XE & 524.8 & 0.889 & & \\
\hline MT_ST & $2,899.8$ & 0.569 & & \\
\hline LOAI_HEM & $-8,427.9$ & 0.033 & & \\
\hline CR_LD & -806.7 & 0.225 & & \\
\hline
\end{tabular}




\begin{tabular}{lcc}
\hline $\mathrm{R}^{2}$ & 0.672 & 0.663 \\
Adjusted $\mathrm{R}^{2}$ & 0.659 & 0.656 \\
F-stat & 50.399 & 90.233 \\
\hline
\end{tabular}

Source: Authors' survey and calculations

The model is finally rewritten as follows:

\section{DON_GIA $=16,535-6,572.1$ AN_NINH $+3,297.9$ CAP_HEM $-2,077.7$ KC_TP + 5,071.2KET_CAU + 29,206.7LOAI_SD + 3,643.7VT_HEM}

Results show that estimators in Model 2 are statistically significant; and adjusted $\mathrm{R}^{2}$ equals 0.656 , which implies that the linear regression model suits the dataset up to $65.5 \%$. In other words, $65.5 \%$ of differences in unit land price can be explained by differences in independent variables. $\mathrm{F}$ value of 90.233 with $\mathrm{Sig} .=0.000<0.05$ implies that the model suits population.

- Multicollinearity Test:

Experience shows that a strong multicollinearity among independent variables usually occurs when $\mathrm{R}^{2}$ is high $(\geq 0.8)$ while $t$-stat is low. In this model, $\mathrm{R}^{2}$ equals $0.663<0.8$, which somehow implies that no strong multicollinearity among independent variables occurs.

To test for multicollinearity, authors perform an auxiliary regression for dependent variable DON_GIA with every independent variable and find that adjusted $R^{2}$ is always lower than $\mathrm{R}^{2}$ in the regression model for all variables. This implies that no multicollinearity exists in this model.

- HeteroskedasticityTest:

We adopt two hypotheses: $\mathrm{H}_{0}$ (homoskedasticity); and $\mathrm{H}_{1}$ (heteroskedasticity).

We perform regression with residual according to independent variables and find that $\mathrm{F}$ is equal to 0.000 and not statistically significant $(\mathrm{Sig} .=1.000>0.05)$. This implies that there is no sign of variation of variance of residuals. In other words, we cannot reject $\mathrm{H}_{0}$ that there is no heteroskedasticity.

- Meanings of Regression Coefficients:

$\mathrm{B}_{2}=-6,572.1$ means that when neighborhood safety increases, or decreases by one degree, unit land price of alley-fronting site will decrease, or increase by VND6,572.1 $/ \mathrm{m}^{2}$ on condition that other factors stay unchanged. 
$\mathrm{B}_{3}=3,297.9$ implies that when grade of alley increases (decreases) by one degree, unit land price of alley-fronting site will increase (decrease) by VND3,297.9/ $\mathrm{m}^{2}$ holding other factors constant.

$\mathrm{B}_{4}=2,077.7$ means that when distance from the property to city center increases or decreases by one minute of motorbike ride, unit land price of alley-fronting site will decrease or increase by VND2,077.7/ $\mathrm{m}^{2}$ holding other factors constant.

$\mathrm{B}_{5}=5,071.2$ means that when alley quality increases or decreases by one degree, unit land price of alley-fronting site will increase or decrease by VND5,071.2/ $\mathrm{m}^{2}$ on condition that other factors stay unchanged

$\mathrm{B}_{6}=29,206.7$ means that when type of land usage increases or decreases by one degree, unit land price of alley-fronting site will increase or decrease by VND29,206.7/ $\mathrm{m}^{2}$ on condition that other factors stay unchanged

$\mathrm{B}_{7}=3,643.7$ means that when alley size increases or decreases by one degree, unit land price of alley-fronting site will increase or decrease by VND $3,643.7 / \mathrm{m}^{2}$ on condition that other factors stay unchanged

\section{b. Model for Street-fronting Properties:}

The results of the first regression with nine variables (Model 1) show that regression coefficients of LOAI_DGT and CR_LD bear negative signs, so they are removed from the model because the signs are contrary to expectation. Then, two variables with no statistical significance $($ Sig. $>0.05)$ - KET_XE (Sig. $=0.928)$, and AN_NINH $($ Sig. $=0,886)-$ are also removed. Model 2 now comprises only five variables as shown in Table 3.

Table 3: Results of Regression Model for Street-fronting Property

\begin{tabular}{lcccc}
\hline \multirow{2}{*}{ Variable } & \multicolumn{2}{c}{ Model 1 } & B & Model 2 \\
\cline { 2 - 5 } & B & Sig. & 60,123 & 0.001 \\
\hline Constant & 100,318 & 0.011 & $10,833.2$ & 0.054 \\
HD_LD & $10,110.1$ & 0.074 & -3525.0 & 0.000 \\
KC_TP & $-3,281.8$ & 0.000 & 940.5 & 0.000 \\
LO_GIOI & $1,057.9$ & 0.000 & $57,637.4$ & 0.000 \\
LOAI_SD & $56,328.6$ & 0.000 & $-21,416.4$ & 0.002 \\
MT_ST & $-24,695.9$ & 0.005 & & \\
AN_NINH & -55.8 & 0.994 & &
\end{tabular}




$\begin{array}{lrrr}\text { KET_XE } & -1,139.8 & 0.969 & \\ \text { LOAI_DGT } & -14,188.3 & 0.081 & \\ \text { CR_LD } & -1,532.2 & 0.066 & \\ \text { R }^{2} & 0.793 & & 0.789 \\ \text { Adjusted R } & & 0.786 \\ \text { F-stat } & 0.787 & & 233.524\end{array}$

Source: Authors' survey and calculation

The model is rewritten as follows:

DON_GIA $=60,123+10,833.2 \mathrm{HD} \_$LD $-3,525.0 \mathrm{KC} \_$TP + 940.5LO_GIOI + 57,637.4LOAI_SD - 21,416.4MT_ST

The results show that estimators in Model 2 are statistically significant; and adjusted $\mathrm{R}^{2}$ equals 0.786 , which implies that the linear regression model suits the dataset up to $78.6 \%$. F-stat is used for testing for fitness of population regression model. The variance test results show the F-value equals 253.524 with Sig. $=0.000<$ 0.05 , which allows us to reject $\mathrm{H}_{0}$, implying the suitability of the multiple linear regression model.

- Multicollinearity Test:

The authors perform an auxiliary regression for dependent variable DON_GIA with every independent variable and find that the adjusted $\mathrm{R}^{2}$ is always lower than $\mathrm{R}^{2}$ in the regression model for all variables. This implies that no multicollinearity exists in this model.

- Heteroskedasticity Test:

The authors adopt two hypotheses: $\mathrm{H}_{0}$ (homoskedasticity); and $\mathrm{H}_{1}$ (heteroskedasticity).

We perform auxiliary regression with residual according to independent variables and find that $\mathrm{F}$ is equal to 0.000 and not statistically significant (Sig. $=1.000>0.05$ ). This implies that there is no sign of variation of variance of residuals. In other words, we cannot reject $\mathrm{H}_{0}$ that there is no heteroskedasticity.

- Meanings of Regression Coefficients: 
$\mathrm{B}_{2}=10.833,2$ means that when shape of the lot gets better (or worse) by one degree, unit land price of street-fronting site will increase (or decrease) by VND10,833.2/ $\mathrm{m}^{2}$ on condition that other factors stay unchanged.

$\mathrm{B}_{3}=-3,525.0$ implies that when distance between the property to city center gets farther (or nearer) by one minute of motorbike ride, unit land price of street-fronting site will decrease (or increase) by VND3,525.0/ $\mathrm{m}^{2}$ on condition that other factors stay unchanged.

$\mathrm{B}_{4}=940.5$ implies that when street size increases (or decreases) by one degree, unit land price of street-fronting site will increase (or decrease) by VND $940,500 / \mathrm{m}^{2}$.

$\mathrm{B}_{5}=57,637.4$ implies that when type of land usage increases (or decreases) by one degree, unit land price of street-fronting site will increase (or decrease) by $57,637.4 / \mathrm{m}^{2}$ on condition that other factors stay unchanged.

$\mathrm{B}_{6}=-21,416.4$ implies that when ecological environment increases (or decreases) by one degree, unit land price of street-fronting site will decrease (or increase) by VND21,416.4/ $\mathrm{m}^{2}$ on condition that other factors stay unchanged.

\section{APPLICATION OF REGRESSION MODEL RESULTS}

Results from the two models are employed to determine land prices in Bình Thạnh District.

\section{a. Alley-fronting Properties:}

The property to be assessed is on alley 91, numbered 91/40, Đinh Tiên Hoàng Street, Ward 3, Bình Thạnh District, HCMC. Codified information about the property is as follows:

AN_NINH: Good (codified as 2)

CAP_HEM: Grade-2 alley (codified as 2)

KC_TP: 7 minutes

KET_CAU: Concrete (codified as 2)

LOAI_SD: For residential purpose (codified as 1)

VT_HEM: 2-meter alley (codified as 2)

Inserting these parameters into the model, the result shows that the land unit price for the assessed property is VND42,078,819 per square meter. 
By applying an ordinary valuation method (comparison), we find that land unit price of this property is VND45,500,000/ $\mathrm{m}^{2}$, implying that difference between results from regression model and comparison method is about $8.5 \%$.

\section{b. Street-fronting Property:}

The property to be estimated is a house numbers 401A on Lê Quang Định Street, Wrad 5, Bình Thạnh District, HCMC with the following codified information:

HD_LD: The lot has not right angles (codified as 1)

KC_TP: 9 minutes

LO_GIOI: About 24 meters

LOAI_SD: Small trading business (codified as 2)

MT_ST: Acceptable (codified as 3)

By inserting these parameters into the model, the result shows that the land unit price for the assessed property is VND112,828,783 per square meter.

By applying an ordinary valuation method (comparison), we find that land unit price of this property is VND1 $14,700,000 / \mathrm{m}^{2}$, implying that difference between results from regression model and comparison method is about $1.68 \%$.

The model can be employed similarly to assess any lot of land in any district in HCMC.

\section{CONCLUSION AND POLICY IMPLICATIONS}

The paper tries to identify and quantify factors that affect the land price in HCMC. All 600 samples employed for the model are properties successfully traded and land prices are pretty exact because they are evaluated by professional assessors. Estimate results show that price of alley-fronting lots is affected by neighborhood safety, alley grade, distance from the lot to city center, alley quality, type of land usage and alley size. Price of streetfronting lots is affected by shape of the lot, distance from the lot to city center, street size, prevailing type of land usage, and ecological environment of the neighborhood.

Comparing results of land valuation by regression model using comparison methods shows that the difference between them is very small, which implies that valuation of land price with regression model approximates the market price with a difference lower than $10 \%$. This result is useful for the task of determining the land price nearing the market price by land authorities. This conclusion implies two significant applications from this model. 
Firstly, research results can be applied to the task of building the pricelist of all kinds of land nearing the market prices conducted annually by HCMC People's Committee to serve as a basis for land granting and leasing.

Secondly, the model of mass appraisal proves to be of high applicability to land valuation for taxation purpose, collection of land use fee and identification of financial obligations for land users because it can be used for evaluating the price of land in a wide area, a district for example, without requiring assessing individual loys of land, thereby reducing time and costs of land valuation.

In sum, mass appraisal of land value helps land authorities determine levels of land prices nearing the market ones based on factors affecting prices of land in specific areas or districts. The biggest challenge and obstacle of the mass appraisal is complexity of regression analysis and the demand for an updated and large dataset. Applying this method therefore requires a data bank that stores information about land prices and all properties traded in the market. With reliable and representative information, the mass appraisal can become a useful instrument for managing the land stock and encouraging development of the economy in general, and of valuation service in particular

\section{References}

Севостьянов, А. В. (2007), “Экономика недвижимости”. М.: Издательство КолосС, pp.227 241.

IAAO (2012), Standard on Mass Appraisal of Real Property, http://www.google.com.vn/url? sa=t\&rct=j\&q=mass+appraisal\&source=web\&cd=5\&ved=0CEw QFjAE\&url=http\%3A\%2F\%2Fwww.iaao.org\%2Fuploads\%2FStandardOnMassAppraisal.pdf\& ei=JtuYT6reAq60iQfwh-WFBg\&usg=AFQjCNHc_itWExDkp_vQkwz-fr3x1ZrwKw\&cad=rja, consulted on Jan. 22, 2012.

Nguyễn Thị Mỹ Linh (2011), “Ú́ng dụng mô hình 'Decision Tree’ trong định giá đất hàng loạt ở VN", Tài chính: No 8 (562) August 2011.

Грабовый П. Г., Кулаков Ю. Н., Лукманова И. Г. и др (1999), Экономика и управление недвижимостью, М.: Издательство АСВ, pp. 218 - 222.

Ramanathan, Ramu (2002), Nhập môn kinh tế lượng với các ưng dụng - 5th ed. http://www.fetp.edu.vn/vn/mpp4/hoc-ky-thu-2011/cac-phuong-phap-dinh-luong/bai-doc/, ngày 09/02/2012.

Turner, M. (2005), “Landscape Preferences and Patterns of Residental Development", Journal of Urban Economics: 57, pp. 19 - 54. 